\title{
The Moderating Effect of Brand Architecture on the Relationship Between Responsiveness and Customer Loyalty Among Telephone Mobile Subscribers in Kenya
}

\author{
Metobo Joseline Kwamboka \\ School of Business and Economics, Department of Marketing and Logistics, \\ Moi University, Eldoret, Kenya \\ Professor Timothy Sulo \\ Department of Agricultural Economics and Resources Management, \\ Moi University, Eldoret, Kenya \\ Professor Michael Korir \\ Department of Management Sciences, Moi University, Eldoret, Kenya
}

Doi: 10.19044/esj.2017.v13n31p248 URL:http://dx.doi.org/10.19044/esj.2017.v13n31p248

\begin{abstract}
The brand architecture of an organization enables customers to enjoy a wide range of services by the same service giver. The purpose of this study was to assess the moderating effect of brand architecture on the relationship between responsiveness and customer loyalty in the mobile telecommunications industry in Kenya. The objectives of the study were to establish the effect of responsiveness on customer loyalty and to find out the moderating effect of brand architecture on the relationship between responsiveness and customer loyalty. An explanatory survey design which is a quantitative research design was adopted. The theory of reasoned action guided the study. The subscribers of the four telecom mobile providers, (Safaricom, Airtel, Telecom Kenya Limited (Orange), and Essar (YU), in Eldoret Town (Western Kenya) were targeted. They totaled over 306,683. A sample size of 500 respondents was selected using stratified and systematic sampling which are probability sampling designs. Questionnaires with Likert scale questions were used to collect data. Multiple regression and Hierarchical moderated regression analysis were used for data analysis. Before brand architecture was introduced into the relationship, it was established that responsiveness determines customer loyalty of mobile subscribers of telecom mobile providers as the four items used had a significant effect on customer loyalty. After the introduction of brand architecture into the relationship it was established that there was both a
\end{abstract}


positive effect and a negative effect. Only one item had a significant effect on customer loyalty. While deciding on offering more services to the subscribers, the telecom mobile providers should know that the relationship between their responsiveness and customer loyalty will change.

Keywords: Brand Architecture, Responsiveness, Customer Loyalty, Moderating

\section{Introdution}

Mobile telecommunication (mobile service provision) refers to the exchange of information, ideas and thoughts through the medium of a mobile phone, telephone or wireless network (Gause, 2007). According to the World International Property Organization (WIPO, 2009), a mobile communication system/network refers generally to any telecommunication system which enables wireless communication when users are moving within the service area of the system. Mobile telecommunication industry is one of the biggest developments of advanced technology and it has become of very big interest now. The world lately has found itself becoming a world village because of the mobile telecommunication network. Many businesses can now go international because of telecommunication. That is why it is important to study its development. Kenya is one country that has embraced the use of the mobile phone.

The telecommunication market is growing in Kenya and so there is competition among the mobile service providers to tap the vast market. Currently there are four mobile telecommunication providers in Kenya which are Safaricom, Airtel, Telecom Kenya Limited (Orange), and Essar (YU). Knowing that customers can move freely from one telecom service provider to another, the telecommunication mobile service providers are looking for ways to enhance customer loyalty which will help them to gain competitive advantage.

Mobile communication network providers, in delivering services to customers, operate in an environment that involves purposeful relationships and interactions between several actors in many activities and with different resources (Scott, 2007). Some of the players in mobile telecommunication industry providing services to customers at their various locations are: the mobile operator who provides the location positioning infrastructure that tells where the customer is; the content provider that delivers the information; the supplier that combines the information with the location information and makes its location relevant; and, the platforms through which the customers can access the services (Harter, Steffano, \& Juanita, 2008). Therefore, it appears that any mobile telecommunication network needs to have key players along its value chain in delivering services to its 
customers (Pura, 2009). The purpose of this study was, therefore, to evaluate the moderating effect of brand architecture on the relationship between responsiveness and customer loyalty among telecommunication mobile service subscribers in Kenya.

Responsiveness is defined as the willingness to help customers and provide prompt service. It means the companies can respond quickly and willingly to the customer's problems, they are ready to serve customers and provide express services. Organizations should be responsive to the shifting needs of their customers. Calling should not be tedious. Use of other software should be simple and understandable. If other programs are introduced, then the customer should be secured. Dale et al., (2007) defines responsiveness as the willingness to assist customers and to provide prompt service on a continuous basis. Sometimes this service may be out of the ambit of normal operating hours. This dimension focuses on attentiveness and willingness in dealing with customer requests, queries and prompt complaint resolution. According to Wang (2003) the responsiveness measures the ability of a company to provide the appropriate information to customers when a problem occurs. The importance of responsiveness in customer perception has been highlighted by researchers (Anthonia, Jeremiah \& Olutayo, 2013).

Brand architecture is the organization and structure of the brand portfolio that specifies brand roles and the nature of brand relationships between brands and between different product-market contexts (Aaker \& Joachimsthaler, 2000). A critical issue for the continued success of organizations is its capability to retain its current customers and make them loyal to its brands (Dekimpe et al., 1997). Loyal customers build businesses by buying more, paying premium prices, and providing new referrals through positive word of mouth over time (Ganesh, Arnold \& Reynolds, 2010). Loyalty research in services is an important area to study (Gremler, 1995).

\section{Statement of the problem}

The telecommunication market is growing in Kenya and so there is competition among the mobile telecom service providers in Kenya, (Safaricom, Airtel, Telecom Kenya Limited (Orange), and Essar (YU), to tap the market. Customers can move freely among the telecom service providers. The mobile service providers are looking for ways to enhance customer loyalty which will help them to gain competitive advantage. In a bid to do so they face many challenges like keeping the customers loyal while at the same time they capture the vast market. They have and are introducing various services to the market in a bid to attract and retain customers and these are of concern because the providers need to make their customers perceive these services as a package and use the entire package. Each of the service 
providers tries to as responsive to customers as possible so that the customer can keep buying from them. The structure of the services offered by the mobile service providers also needs to be structured in a manner that customers understand. The structure of these services (brand architecture) in such a way as to enhance customer loyalty which leads to competitive advantage is a major challenge to the mobile service providers. Customers may prefer to use one service but not another by the same provider. This may be partly because of the response they receive from the service givers. With this kind of situation, there is need to explore how telecom mobile providers' brand architecture affects the subscribers' perception of responsiveness and customer loyalty. Siew-Phaik, Ayunkunle, Hanisah, \& Alan (2011) found out that responsiveness heavily impacts on customers in the telecommunications industry. Jyotsna (2012) found out that customers were dissatisfied with the way organizations were handling responsiveness. Customers wanted more attention given to it. These studies were done outside Kenya and since the telecommunication industry is fast growing in Kenya, there is need to need to stablish how brand architecture affects the relationship between responsiveness and customer loyalty. It has also been established that there is very limited documentation on brand architecture as a moderation in the relationship between responsiveness and customer loyalty. So this study set out to find out the moderating effects of brand architecture on the relationship between responsiveness and customer loyalty.

\section{The purpose of the study}

The purpose of the study was to find out the moderating effect of brand architecture on the relationship between responsiveness and customer loyalty among mobile service subscribers in Kenya.

\section{Specific objectives}

The specific objectives of the study were:

a. To establish the effect of responsiveness on customer loyalty among mobile telecom subscribers in Kenya

b. To find out the moderating effect of brand architecture on the relationship between responsiveness and customer loyalty among mobile telecom subscribers in Kenya

\section{Research hypothesis}

$\mathrm{HO}_{1}$ : Responsiveness of the service provider does not significantly affect customer loyalty.

$\mathrm{HO}_{2}$ : Brand architecture of the company does not moderate the relationship between responsiveness and customer loyalty. 


\section{Significance of the study}

The findings of this study will be of significance to various stakeholders. The findings will be significant to business and marketing practitioners, policy makers and stakeholders in the telecommunication industry. To the management of Kenya's mobile telecommunication networks, the findings will provide a more reliable /scientific measure and perspective for describing and evaluating the level of their customer satisfaction with the services they deliver to them. The findings will serve as an invaluable source of information that will bring to the lime light the kind of response customers expect to get from service providers.

This will provide empirical support to strategic decisions by different managements in the telecommunication industry in the designing of workable service delivery improvement strategies. The findings of this study will provide invaluable insights as well as a more reliable guide to monitoring operations of different service providers in the country. To stakeholders such as investors, shareholders, pressure groups and consumer associations, the findings will provide information that will allow them to provide useful suggestions to the improvement in service delivery of the various mobile service providers in Kenya. The findings will add to the pool of knowledge on responsiveness and hence form a basis for further studies.

In addition, the study avails valuable information to researchers interested to do more research on this topic as the document will be made available in the library for perusal and use by other researchers. The information from the research study may also benefit the general public in understanding the main issues relating to brand architecture, responsiveness and customer loyalty.

\section{Theoretical framework}

This study was guided by the theory of reasoned action and theory of planned action.

The Theory of Reasoned action (TRA) is a model for the prediction of behavioral intention, spanning predictions of attitude and predictions of behavior. The subsequent separation of behavioral intention from behavior allows for explanation of limiting factor on attitudinal influence (Ajzen and Fishbein, 1980). The theory of Reasoned Action was developed by Fishbein and Ajzen (1975, 1980), derived from previous research started out as the theory of attitude which led to the study of attitude and behavior.

The Theory of Reasoned action can be applied to explain how consumer attitudes and beliefs lead to a certain buying behavior. According to the theory, the most important determinant of a person's behavior is intent. The components of TRA are three general constructs: behavioral intention (BI), attitude toward performing the behavior (AB), and subjective norms 
(SN). TRA suggests that a person's behavioral intention depends on the person's attitude about the behavior and subjective norms. The two antecedents influence the intention behavior $(\mathrm{BI}=\mathrm{AB}+\mathrm{SN})$. A consumer's response to each element of TRA (AB: attitude toward the purchase behavior, SN: subjective norm, IB: Intention purchase behavior) will lead to actual brand loyalty. If all the three elements are shown favorable the brand loyalty will be regarded as maximum.

\section{Conceptual framework}

The study adopted a conceptual framework which is a diagrammatic representation of the hypothesized relationship between dependent and independent variables in the study. It shows, firstly, the effect of responsiveness on customer loyalty among mobile telecom subscribers in Kenya and secondly, the moderating effect of brand architecture on the relationship between responsiveness and customer loyalty among mobile telecom subscribers in Kenya.

Independent Variables

Dependent Variable

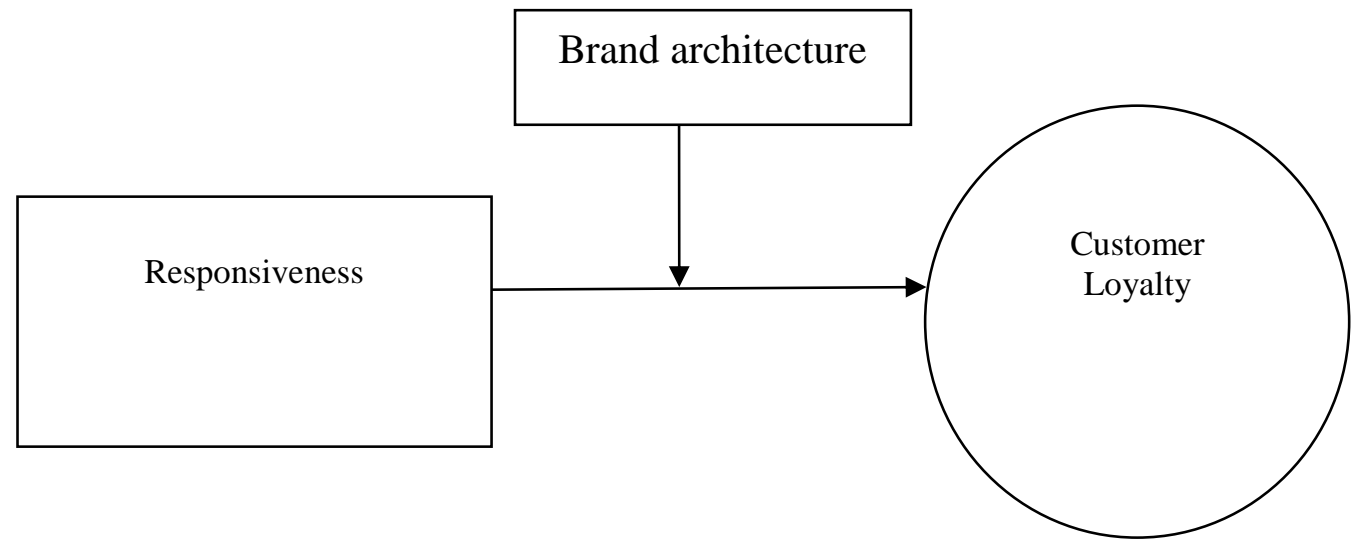

Figure 1.0 Conceptual model of Responsiveness, Brand Architecture and Customer Loyalty

\section{Research methodology \\ Philosophical Paradigm}

Philosophical worldview refers to the basic set of beliefs that guide actions, also known as paradigms, epistemologies and ontologies (Creswell, 2009). It is the general orientation about the world and the nature of research that the researcher holds, which leads to the researcher embracing either qualitative, quantitative or mixed methods approaches. It consists of philosophical assumptions that guide and direct thinking and action. There are four different worldviews: post positivism, constructivism, advocacy/participatory and pragmatism. Post positivism holds that causes determine effects or outcomes and that knowledge develops through careful 
observation and measurement of objective reality that exists out there in the world. It deals with testing laws and theories to verify or confirm so as to understand the world. Hence it advocates for quantitative approaches. This study adopted the post positivism which makes it quantitative.

\section{Research design}

This study adopted an explanatory survey design. This is a design used to investigate large populations by selecting samples to analyze and discover occurrences. The design involves observing and describing the general behavior of subjects without influencing them in any way (Shuttleworth, 2008). The purpose of using the survey design for this study was to provide numeric descriptions of some part of the population. The researcher then described and explained events as they would be. The telecom mobile subscribers of the four telecom mobile providers in Western Kenya formed the target population. The study further targeted all mobile service subscribers of (Safaricom, Airtel, Telecom Kenya Limited (Orange), and Essar (YU), of Eldoret town who totaled over 306,683.

\section{Sampling Design and Sample Size}

The researcher selected a sample of mobile service subscribers of the four mobile service providers which was as representative as possible, using stratified and systematic sampling technique. This was a probability sampling technique. The basis of stratification was the four different mobile service providers. A sample size of 500 respondents was used for the study. For this study, questionnaires used were developed with the help of previous survey studies on customer perception and customer loyalty (Bonuke, 2010).

\section{Research Instruments and Data Analysis Techniques}

The questionnaire comprised of items covering all the objectives of the study. The items were rated on a 7-point Likert scale. The questionnaires were checked, edited, coded and keyed in the computer using SPSS data entry form. They, then, were analyzed using descriptive statistics. Multiple regression analysis was used to test the effects of responsiveness on customer loyalty. Moderated regression analysis was used to test the moderating effect of brand architecture on the relationship between responsiveness and customer loyalty. The level of significance was set at 95\% or p-value of 0.05.This resulted in percentages, frequencies, means, standard deviations which were presented in frequency tables.

\section{Model Specification}

The simple linear regression equations tested the relationship between the independent variable the dependent variables. Multiple 
regression equation tested the relationship between responsiveness and customer loyalty.

Where:

$\mathrm{CL}=\alpha+\beta \mathrm{RES}+\varepsilon$

$\alpha=$ Constant/intercept

$\beta=$ Coefficient

RES=Responsiveness

$\varepsilon=$ error term

In the model the variable CL (customer loyalty) is a function of the intercept $(\alpha)$, responsiveness and the residual error.

$\mathrm{CL}=\alpha+\beta \mathrm{RESBAC}+\varepsilon$

$\mathrm{BAC}=$ Brand Architecture

This model includes Responsiveness (RES), brand architecture (BAC) and customer loyalty (CL) in order to account for potential interaction effect of brand architecture.

The moderated regression equation tested the relationship between responsiveness, brand architecture and customer loyalty. Moderated regression analysis is an analytic approach which maintains the integrity of a sample yet provides a basis for controlling the effects of a moderator variable. By this procedure, the loss of information resulting from the artificial transformation of a continuous variable into a qualitative one is avoided. Utilization of the data is nearly complete (Zedeck, Cranny, Carol, Patricia, Smith, 1971).

\section{Summary of findings, conclusions and recommendations Summary of Findings}

The study sought to find out the respondents' position on the responsiveness of the provider in order to establish the effects of responsiveness on customer loyalty of telecom mobile providers.

The model $\mathrm{R}^{2}$ is $.245(24.5 \%)$ which means that the total variance explained by the three items and customer loyalty is $24.5 \%$. This implies that there are other variables which must explain customer loyalty.

Table 1: Effects Model Summary

\begin{tabular}{|c|c|c|c|c|c|c|c|}
\hline Model & $\mathrm{R}$ & $\mathrm{R}$ Square & $\begin{array}{c}\text { Adjusted R } \\
\text { Square }\end{array}$ & & $\begin{array}{l}\text { Std. Error of } \\
\text { the Estimate }\end{array}$ & \multicolumn{4}{|l|}{} \\
\cline { 5 - 8 } & & & & $\begin{array}{c}\text { R Square } \\
\text { Change }\end{array}$ & F Change & $\begin{array}{c}\text { Sig. F } \\
\text { Change }\end{array}$ \\
\hline 1 & $.495^{\mathrm{a}}$ & .245 & .239 & .87232498 & .245 & 40.190 & .000 \\
\hline
\end{tabular}

Also the ANOVA results showed that the four items that measured responsiveness were highly significant at .000 . The items used were "The contact employees tell me exactly when the services will be performed", "I 
receive prompt service from the contact employees", "The contact employees are always willing to help", and "The contact employees resolve my complaints quickly".

Table 2: Effects ANOVA

ANOVA $^{\mathrm{a}}$

\begin{tabular}{|cc|c|c|c|c|c|}
\hline \multicolumn{1}{|c|}{ Model } & Sum of Squares & df & Mean Square & F & Sig. \\
\hline \multirow{4}{*}{1} & Regression & 122.329 & 4 & 30.582 & 40.190 & $.000^{\mathrm{b}}$ \\
& Residual & 376.671 & 495 & .761 & & \\
& Total & 499.000 & 499 & & & \\
\hline
\end{tabular}

a. Dependent Variable: Zscore(CustomerL)

b. Predictors: (Constant), resr, resc, resp, resw

The results for "The contact employees tell me exactly when the services will be performed", were beta $=.141$ and $p$ - value $=.004$. This implies that for every unit change in this item customer loyalty increases by $14.1 \%$ and this makes a highly significant change in customer loyalty.

The results for "I receive prompt service from the contact employees", were beta $=.174$ and $p$ - value $=.001$. This implies that for every unit change in this item customer loyalty increases by $17.4 \%$ and this makes a significant change in customer loyalty.

The results for the item "The contact employees are always willing to help", were beta $=.176$ and $\mathrm{p}$ - value $=.002$. This implies that for every unit change in this item customer loyalty increases by $17.6 \%$ and this makes a highly significant change in customer loyalty.

The results for the item "The contact employees resolve my complaints quickly" were beta $=.115$ and $p$ - value $=.031$. This implies that for every unit change in this item customer loyalty increases by $11.5 \%$ and this makes a highly significant change in customer loyalty.

Table 3: Effects Coefficients

Coefficients $^{\mathrm{a}}$

\begin{tabular}{|c|c|c|c|c|c|c|}
\hline & \multirow[t]{2}{*}{ Model } & \multicolumn{2}{|c|}{ Unstandardized Coefficients } & Standardized & \multirow[t]{2}{*}{$\mathrm{t}$} & \multirow[t]{2}{*}{ Sig. } \\
\hline & & B & Std. Error & Beta & & \\
\hline \multirow{5}{*}{1} & (Constant) & -1.672 & .138 & & -12.106 & .000 \\
\hline & resc & .077 & .027 & .141 & 2.874 & .004 \\
\hline & resp & .097 & .029 & .174 & 3.321 & .001 \\
\hline & resw & .101 & .032 & .176 & 3.137 & .002 \\
\hline & resr & .060 & .028 & .115 & 2.163 & .031 \\
\hline
\end{tabular}

a. Dependent Variable: Zscore(CustomerL)

\section{Moderation hypothesis testing}

This study set to find out the moderating effect of brand architecture on the relationship between responsiveness and customer loyalty. A 
hierarchical moderation regression analysis was carried out. The results indicate that when the moderator variable is interacted with the independent variable the relationships change. The model summary table shows that the $\mathrm{R}^{2}$ shifts from .245 to .932 when brand architecture is introduced. This signifies that the moderator does change the relationship between tangibility and customer loyalty.

Table 4: Moderator Effects Model Summary

\begin{tabular}{|c|c|c|c|c|c|c|}
\hline \multirow[t]{2}{*}{ Model } & \multirow[t]{2}{*}{$\mathrm{R}$} & \multirow[t]{2}{*}{ R Square } & \multirow{2}{*}{$\begin{array}{l}\text { Adjusted R } \\
\text { Square }\end{array}$} & \multirow{2}{*}{$\begin{array}{l}\text { Std. Error of } \\
\text { the Estimate }\end{array}$} & & \\
\hline & & & & & $\begin{array}{l}\text { R Square } \\
\text { Change }\end{array}$ & Sig. F Change \\
\hline 1 & $.495^{\mathrm{a}}$ & .245 & .239 & .87232498 & .245 & .000 \\
\hline 2 & $.540^{\mathrm{b}}$ & .291 & .284 & .84618732 & .046 & .000 \\
\hline
\end{tabular}

The ANOVA results indicate that responsiveness and brand architecture were very significant (at .000) to customer loyalty.

Table 5: Moderator Effects ANOVA

ANOVA $^{\mathrm{a}}$

\begin{tabular}{|c|c|c|c|c|c|c|}
\hline & Model & Sum of Squares & df & Mean Square & $\mathrm{F}$ & Sig. \\
\hline \multirow{3}{*}{1} & Regression & 122.329 & 4 & 30.582 & 40.190 & $.000^{\mathrm{b}}$ \\
\hline & Residual & 376.671 & 495 & .761 & & \\
\hline & Total & 499.000 & 499 & & & \\
\hline \multirow{3}{*}{2} & Regression & 145.280 & 5 & 29.056 & 40.579 & $.000^{\mathrm{c}}$ \\
\hline & Residual & 353.720 & 494 & .716 & & \\
\hline & Total & 499.000 & 499 & & & \\
\hline
\end{tabular}

a. Dependent Variable: Zscore(CustomerL)

b. Predictors: (Constant), resr, resc, resp, resw

c. Predictors: (Constant), resr, resc, resp, resw, Zscore(ProviderBill)

The results for the dependent variable ( $\mathrm{p}$ - values) changed when the moderator (brand architecture) was introduced into the relationship. A beta coefficient of 0.039 indicates that customer loyalty would increase by 0.039 standard deviations given a unit change in the item "The contact employees resolve my complaints quickly". Brand architecture's beta coefficient was at 0.943 which means customer loyalty increases by 0.943 standard deviations given a unit change in brand architecture. With the introduction of the moderator variable only the item "The contact employees resolve my complaints quickly" had a significant effect on customer loyalty. The items, "The contact employees tell me exactly when the services will be performed", "I receive prompt service from the contact employees", and "The contact employees are always willing to help", become insignificant. This signifies that brand architecture moderates the relationship between tangibles and customer loyalty. 
Table 6: Moderator Effects Coefficients

Coefficients $^{\mathrm{a}}$

\begin{tabular}{|c|c|c|c|c|c|c|}
\hline \multirow{2}{*}{\multicolumn{2}{|c|}{ Model }} & \multicolumn{2}{|c|}{$\begin{array}{l}\text { Unstandardized } \\
\text { Coefficients }\end{array}$} & $\begin{array}{l}\text { Standardized } \\
\text { Coefficients }\end{array}$ & \multirow[t]{2}{*}{$\mathrm{t}$} & \multirow[t]{2}{*}{ Sig. } \\
\hline & & $\mathrm{B}$ & Std. Error & Beta & & \\
\hline \multirow{5}{*}{1} & (Constant) & -1.672 & .138 & & -12.106 & .000 \\
\hline & resc & .077 & .027 & .141 & 2.874 & .004 \\
\hline & resp & .097 & .029 & .174 & 3.321 & .001 \\
\hline & resw & .101 & .032 & .176 & 3.137 & .002 \\
\hline & resr & .060 & .028 & .115 & 2.163 & .031 \\
\hline & (Constant) & -.147 & .047 & & -3.153 & .002 \\
\hline \multirow{5}{*}{2} & resc & .002 & .008 & .004 & .250 & .803 \\
\hline & resp & .007 & .009 & .012 & .741 & .459 \\
\hline & resw & .001 & .010 & .002 & .144 & .886 \\
\hline & resr & .020 & .008 & .039 & 2.432 & .015 \\
\hline & Zscore(BrandArch) & .943 & 013 & .943 & 70.888 & .000 \\
\hline
\end{tabular}

a. Dependent Variable: Zscore(CustomerL)

\section{Conclusion}

It is evidently clear from the study findings that brand architecture of a telecom mobile provider has a bearing on the relationship between responsiveness and customer loyalty of mobile telecommunication subscribers. It is evident that the brand architecture of the telecom mobile prover significantly moderates the relationship between responsiveness and customer loyalty. Responsiveness determines customer loyalty of mobile subscribers of telecom mobile providers in a number of ways.

Firstly, customers assess the promptness and sincerity of information on when the service will be performed. Secondly, mobile subscribers choose and become loyal to a provider who promptly responds to customer concerns. Thirdly, mobile subscribers choose and become loyal to a service provider who is willing to help. Fourthly, mobile subscribers choose and become loyal to a service provider who is willing to resolve complaints quickly.

\section{Recommendations}

While deciding on the on the number of products to offer to the market, the telecommunication providers should think of how they can respond to customers promptly. This is because subscribers appreciate and choose providers who respond fast.

Telecom mobile providers should make sure that they have contact employees who are willing to help subscribers. The employees should also be those who are willing to solve their complaints quickly. 


\section{References:}

1. Aaker, D., \& Joachimsthaler, E. (2000). The Brand Relationship Spectrum: The Key to the Brand Architecture Challenge. California Management Review, 8-23.

2. Fishbein, M., \& Ajzen, I. (1975). Belief, attitude, intention and behavior: An intro-duction to theory and research. Reading, MA: Addison-Wesley.

3. Ajzen, I. and Fishbein, M. (1980). Understanding Attitudes and Predicting Social Behavior. Englewood Cliffs, New Jersey: PrenticeHall

4. Anthonia, C., Iyamabo, J., and Otubanjo, O. (2013). Investigating Service Responsiveness in Customer Perception of the Corporate Logo. International Journal of Business and Management, Vol. 8, No. 11; 2013.

5. Bonuke, R. N. (2011). The Moderating Effects of Multichannel Service on Relationship Quality and Customer Loyalty in Banks. A Thesis Presented to the School of Business and Economics, Eldoret: Moi University.

6. Creswell, J. N. (2009). Research Design: Qualitative, Quantitative and Mixed Methods Approaches. ( $3^{\text {rd }}$ ed.). Los Angeles: Sage Publications, Inc

7. Dale, B. G., Van der Wiele, T., and Van Iwaarden, J. (2007). Managing Quality (5 ${ }^{\text {th }}$ ed). Oxford: Blackwell Publishing.

8. Dekimpe, M. G., Steenkamp, J., Mellens, M., and Abeele, P. V. (1997). Decline and Variability in Brand Loyalty. International Journal of Research in Marketing, 14, 405-420.

9. Ganesh, J, Arnold, MJ, Reynolds, KE, Ganesh, J. (2000). Understanding the customer base of service providers: An examination of the differences between switchers and stayers. Journal of Marketing, 64(3), 65-87.

10. Gause, A. (2007). E-Satisfaction-A Comprehensive Framework. International Marketing, European Journal of Business And Management, Vol. 5, No. 23 Pg 26-3

11. Gremler, K. (1995). Transmission Quality of Evolving Telephone Services. IEEE Communications Magazine, 26(10), 24-35.

12. Hart, P., Steffano, K., and Juanita, E. (2008). The E-commerce Book: Building the E-empire. San Diego, Calif. U.A. Academic, 2001. Print.

13. Jyotsna, H., (2012), Measuring Internal Customer's Perception on Service Quality Using SERVEQUAL in Administrative Services. International Journal of Science and Research Publications, 2 (3), 2250-3153. 
14. Pura, G. (2009). E-commerce: the role of familiarity and trust. The international Journal of management science Omega 28 (2000) 725737.

15. Scott, D. (2007). E-business and E-commerce Management: Strategy, Implementation and Practice. (4 ${ }^{\text {th }}$ ed.) Harlow, England: FT Prentice Hall. Print.

16. Siew Phaik, Ayankunle Adegbite Taiwo, Hanisah Mat Salim and Alan G. Downe, (2011). Service Quality and Customer Satisfaction in Telecomunication Service Provider: International Conference on Financial Management and Economics. IPEDR, Vol.11, LACSIT Press, Singapore.

17. Martyn Shuttleworth (Sep 26, 2008). Descriptive Research Design. Retrieved Jun 03, 2017 from Explorable.com: https://explorable.com/descriptive-research-design

18. Wang, M. (2003). Assessment of E-Service quality via $E$ Satisfaction in E-Commerce Globalization.

19. WIPO (2009). World Intellectual Property Organization.

20. Zedeck,S. C., Cranny, J., Carol, A., and Smith, P. C. (1971). Comparison of Joint Moderators in Three Prediction Techniques. Journal of Applied Psychology, 55, 234-240.

\section{APPENDIX 1: MAP OF STUDY LOCATION}

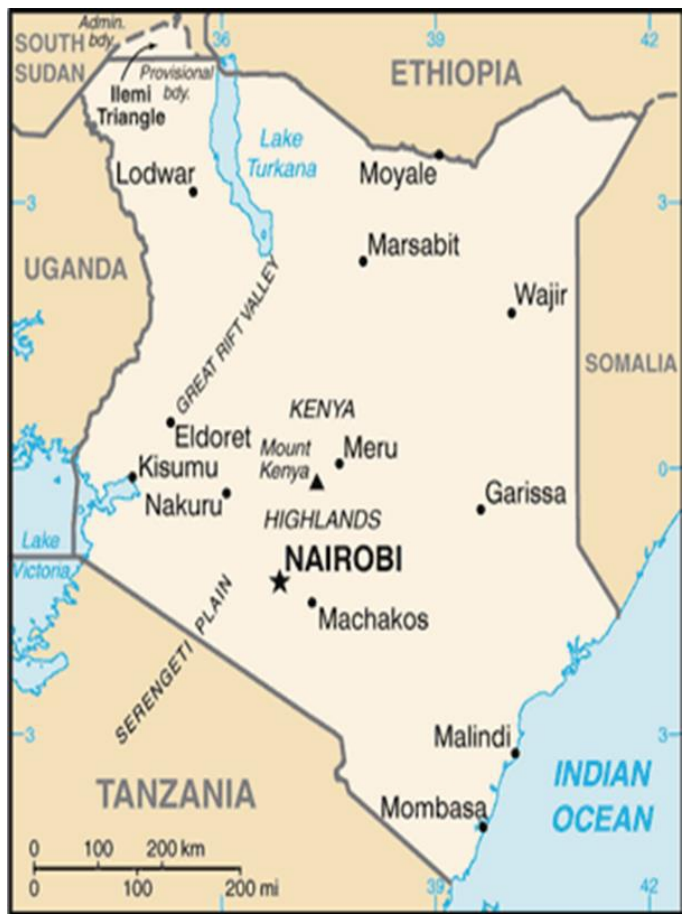

